ticular form. A number of patients are excluded from these results on the grounds of " advanced diseases or other reason." Those exclusions rise as high as 354 out of 892 patients seen with cancer of the hypopharynx (p. 33), so that a considerable element of selection appears to be taking place.

If in future editions of this useful book figures are also given as described by Macdonald, ${ }^{1}$ Berkson and Gage, ${ }^{2}$ or MacComb, ${ }^{3}$ the appropriate corrections can be made when necessary to make these results comparable with other series.-I am, etc.,

$$
\text { Hull. }
$$

$$
\text { R. G. Williams. }
$$

REFERENCES

1 Macdonald, E. J., Amer. 7. Roentgenol., 1948,

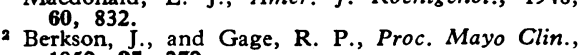
1950, 25, 270.

S MacComb, W. S., Amer. F. Surg., 1967, 114,
486.

\section{Hookworm Infection}

SIR,-I was pleased to read your leading article about hookworm infection. (28 December, p. 788). You state that the overall rate of infection in people coming from overseas is unknown, but $8 \%$ of immigrant school children examined in Bradford showed hookworm ova in the stools.

In Cwmbran, immigrants working at catering establishments and some others have been investigated for helminths and organisms since 1965. The Chinese from Hong Kong have been very co-operative and anxious to ensure that they are not infected. The following Table, although the number investigated is small and includes adults and children, may be of interest.

Immigrants Investigated for Hookworm and

\begin{tabular}{|c|c|c|}
\hline & $\begin{array}{l}\text { Hong } \\
\text { Kong }\end{array}$ & $\begin{array}{l}\text { India and } \\
\text { Pakistan }\end{array}$ \\
\hline 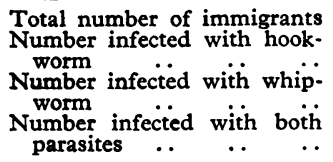 & $\begin{array}{r}44 \\
9 \\
24 \\
8\end{array}$ & $\begin{array}{r}11 \\
4 \\
3 \\
3\end{array}$ \\
\hline
\end{tabular}
Whipworm 1965-7

You will observe that infection with hookworm varies from one-fifth to one-third of those investigated.

Some immigrants seen and treated in 1965 had been resident in this country for four years. Complaints of abdominal pain were made before treatment in some cases. No immigrant appeared to suffer from anaemia. The incidence of infection varied with social class ; restaurant owner/managers and professional persons, for example, doctors and surveyors, were not infected. The four children examined and treated have gained in weight and height since arriving in Cwmbran.

I had always assumed that the hookworm infection was $A$. duodenale. One dose of 5 g. of bephenium hydroxynaphthoate has been sufficient to clear the stools of ova. The treatment of whipworm is more difficult. All Chinese investigated have been treated and the infection eliminated, either by one or two courses of bephenium hydroxynaphthoate, 5 g. nightly for 5 nights, or by referring to hospital for treatment with dithiazanine iodide. The latter course was necessary in the case of two children.

You state that infection with hookworm in people who have never been out of this country is unusual. Even so, I consider that all immigrants should be investigated and treated to ensure that they are not infected with parasites. One outbreak of whipworm infection in this country in 1968 is known to me. This was of 17 cases at a hospital for the care of the mentally subnormal. The original source of the infection was not elucidated.-I am, etc.,

$$
\begin{aligned}
& \text { Public Health Department, } \\
& \text { Cwmbran, Mon. }
\end{aligned}
$$

$$
\text { H. G. Jenkins. }
$$

\section{Peritoneal Dialysis Assembly}

SIR,-We wish to draw your attention to the fact that there is at the present time satisfactory apparatus commercially available for the delivery and drainage of peritoneal dialysis fluid.

Baxter Laboratories Ltd. have developed a complete range of equipment for this procedure, which comprises Dianeal solutions, a Y-type administration set with drainage tubing, catheter, and 3-litre drainage bag. This equipment is designed to relieve the hospital staff of the time-consuming assembly procedures which were described by $\mathrm{Mr}$. R. W. Lloyd-Davies and his colleagues (21 December, p. 757).-We are, etc.

$$
\begin{aligned}
& \text { J. A. WheEler-BenNetT, } \\
& \text { P. IRVING. } \\
& \text { Medical Director. }
\end{aligned}
$$

SIR,-I have seen the letter from Baxter Laboratories Ltd. on this subject. The total cost of their Br61L Y-type administration set with drainage tubing and their 3-litre drainage bag (R-61D) is 25s. 6d. This is twice the cost of the set that is made routinely in the Central Sterile Supply Department of St. Thomas's Hospital. Each set takes but five minutes to make up, and, furthermore, meets our requirements for single-litre exchanges only. I think it is important to stress the ease of making up such equipment from standard components, together with their low cost to the National Health Service, considering the amount of dialysis being carried out at the present time.-I am, etc.,

$$
\begin{aligned}
& \text { R. W. LLOYD-DAvies. } \\
& \text { Department of Urology, } \\
& \text { St. Thomas's Hospital, } \\
& \text { London S.E.1. }
\end{aligned}
$$

\section{Solvents for Ear Wax}

SIR,-I have been not a little surprised to find no reference made, other than by $\mathrm{Dr}$. H. G. Morris-Jones (28 December, p. 835), to the use of sodium bicarbonate as a preparatory instillation before syringing.

I was taught to use this very many years ago, and have done so ever since with only one complete failure. Sodium bicarbonate is not, of course, a solvent, but as a preparatory agent it is in my experience unrivalled. Apart from the incident previously mentioned, the only difficulties I encounter are in those patients who have got an accumulation of desquamated epithelium or whose meati are excessively endowed with hairs. The strength that I advise is half a teaspoonful dissolved in half a cupful of warm water.-I am, etc.,

$$
\begin{gathered}
\text { Bakewell, } \\
\text { Derbyshire. }
\end{gathered}
$$$$
\text { H. G. WATSON. }
$$

\section{Management of Coronary Artery Disease}

SIR,-In the article on the management of coronary artery disease (4 January, $p$. 37) the following comment appears in relation to propranolol: "The dose, however, required to control angina sometimes far exceeds that needed to effect complete beta receptor blockade. Propranolol must therefore exert other actions which contribute to its beneficial effect in this disease, and one of these is a quinidine-like depressant action on the myocardium."

There are two points in this paragraph which require comment in order to prevent confusion in the minds of your readers. Firstly, the dose of propranolol to produce " complete beta receptor blockade" is entirely arbitrary, being dependent on the pre-existing level of stimulation, as is the case with all competitive antagonists. Assessment of betablockade may be determined by the extent to which the response to a specific beta receptor stimulant is reduced-for example, isoprenaline tachycardia, or physiological responses to exercise or tilting. Determination of the level of sympathetic stimulation or myocardial noradrenaline release is not a practical possibility at the present time, and there is no way of knowing how closely a provoked response in volunteers matches that present in patients with angina. Secondly, the inference from a difference in dose levels that beta receptor blockade is not the mechanism of action in angina is only tenable if clear-cut differences in dose levels have been shown.

Analysis of seven clinical studies in which isoprenaline tachycardia $(0.03 \mu \mathrm{g} . / \mathrm{kg}$.) was used to determine beta-blockade shows the mean dose of propranolol to abolish the response to be $0.12 \pm 0.02 \mathrm{mg} . / \mathrm{kg}$. intravenously. In four clinical evaluations of intravenous propranolol in 67 anginal patients, objective improvements were observed in 62 patients, with respect to exercise tolerance or E.C.G. changes at a mean dose level of $0.08 \mathrm{mg} . / \mathrm{kg}$. In single oral dose trials it was found that $50 \mathrm{mg}$. propranolol reduced exercise tachycardia to $75 \%$ of the reduction observed after sympathectomy. ${ }^{1}$ In three clinical single-dose studies objective improvements in exercise E.C.G. patterns were observed in all of 42 anginal patients following the mean dose of $50 \mathrm{mg}$. propranolol- - that is, $0.7 \mathrm{mg} . / \mathrm{kg}$. in both contexts assuming a mean body weight of $70 \mathrm{~kg}$.

In chronic trials it must be remembered that dosage recommendations (q.d.s.) are intended to provide 24-hour blockade of sympathetic beta receptor activity as opposed to the short-term effect (up to 2 hours) in the single-dose studies. This is particularly important for a drug with an estimated half-life of only 2-3 hours. In 11 chronic oral trials involving 221 anginal patients 169 showed objective improvements in effort tolerance or E.C.G. at a mean daily dose of 159 mg. (or $2.3 \mathrm{mg} . / \mathrm{kg}$.). In 17 double-blind trials 279 anginal patients from a total of 370 had subjective improvements on a mean daily dóse of $162 \mathrm{mg}$. If one assumes that self-dosing provides effective blood levels of the drug for 18 